logos_i_ethos_2014_1_(36), s.247-250

Joanna Mysona Byrska

\title{
Nieutylitarystyczny konsekwencjonalizm - projekt etyczny dla XXI wieku
}

\section{Vasil Gluchman, Etyka społecznych konsekwencji, tłum. Przemysław Kroczek, wyd. Humanum, Warszawa 2012}

Etyka społecznych konsekwencji prezentowana $\mathrm{w}$ książce pod tym samym tytułem jest autorskim projektem Vasila Gluchmana, profesora filozofii i etyki, który podjął się trudnego zadania stworzenia własnej koncepcji etycznej na miarę współczesnych czasów. Celem pracy jest zwrócenie uwagi polskiego czytelnika na wersję nieutylitarystycznego konsekwencjonalizmu, czyli tytułową etykę

Joanna Mysona Byrska - doktor habilitowana, Kierownik Katedry Filozofii Społecznej i Polityki (Wydział Filozoficzny UPJPII). Zainteresowania: etyka, filozofia społeczna, filozofia polityki, etyka stosowana, Publikacje: Demokratyczne państwo prawa $i$ jego znaczenie dla czlowieka w myśli Ernsta Wolfganga Böckenfördego, Kraków 2005; Etyczne aspekty demokracji, Kraków 2012. społecznych konsekwencji. Wydaje się, że jest to ważna próba uzupełnienia istotnej luki w polskiej literaturze etycznej, w której nie znajdziemy żadnej istotnie ważnej monografii na temat konsekwencjonalizmu, zwłaszcza w wersji nieutylitarystycznej. Nieutylitarystyczny konsekwencjonalizm można by uznać ze pewną próbę przeciwstawienia się rozpowszechnionemu konsumpcjonizmowi opartemu na wartościach utylitarystycznych. Można również zastanawiać się, na ile nieutylitarystyczny konsekwencjonalizm proponowany przez Gluchmana mógłby być przeciwwagą dla rozpowszechnionego współcześnie rynkowego tryumfalizmu, który wydaje się być w stanie wszystko opatrzyć metką z ceną, czyli przeliczyć na mierzalne i wymierne środki finansowe.

Etyka społecznych konsekwencji, czyli nieutylitarystyczny konsekwencjonalizm proponowany przez Gluchmana, przyjmuje, że ramy 
tego, czym jest dobro i jak jest rozumiane, są tworzone w oparciu o społeczne konsekwencje ludzkiego działania. Dobrem, jak pisze Gluchman, jest „wszystko to, co wypełnia życie człowieka radością, szczęściem, sielanką i pokojem, zabezpieczeniem socjalnym, poczuciem bezpieczeństwa, spokoju" ${ }^{1}$. Przy czym należy pamiętać, że kryterium oceny stopnia dobra danego działania i jego konsekwencji jest sprawiedliwość, która określa, jak dobro należy rozumieć w społecznych kontekstach.

Etyka społecznych konsekwencji jawi się zatem jako teoria słusznego działania i wydaje się być oryginalnym autorskim projektem odpowiedzi na współczesny kryzys wartości. Rozwiązania tego kryzysu poszukiwane są w społecznych kontekstach. Wydaje się, że Gluchman w swoim etycznym projekcie przyjmuje pozytywną rolę społeczeństwa oraz zakłada jego możliwości wpływu na dobrostan jednostki. Z wielu szczegółowych kwestii podejmowanych w książce na uwagę zasługuje problematyka godności człowieka, kwestii biologicznych związanych z ludzkim życiem, wreszcie pytanie o prawo moralne i jego współczesne formy filozoficzne i etyczne.

Kreśląc swój autorski projekt, Gluchman zaprasza do debaty nad przedstawionymi poglądami. Projekt nieutylitarystycznego konsekwencjonalizmu jest zatem w zamierzeniu autora dziełem, które ma intrygować i wywoływać debatę, namysł etyczny nad kwestiami etycznymi. Gluchmana interesują zwłaszcza krytyczne oceny, ponieważ tylko rzetelna krytyka pozwala autorowi w sposób twórczy podejść do własnej koncepcji. Gdy pyta o źródła etyki, przyjmuje, że w pewnej mierze moralność powstaje pod wpływem biologicznych i społecznych determinantów. Jednostka w grupie ma większe szanse przeżycia oraz lepszej egzystencji. Jej życie może mieć lepszą jakość dzięki współegzystencji z innymi. Zgodnie z tym, co twierdzą socjobiolodzy, nowi darwiniści i etycy ewolucyjni, moralność ludzka ma swoją pierwotną podstawę biologiczną - stwierdza Gluchman. Dla etyki społecznych konsekwencji biologiczne podstawy ludzkiej moralności pozostają wprawdzie ważne, ale większą 
rolę odgrywają społeczne aspekty, które wydają się pozostawać sprzeczne $\mathrm{z}$ walką o przeżycie, a stanowią bardzo ważny determinant ludzkiej moralności. Człowiek jest istotą społeczną, jest refleksyjnym podmiotem moralnym, a to pozwala mu przekraczać biologiczne determinanty i realizować coś więcej niż wynika to z determinacji czysto biologicznej.

Jedną z ważnych tez stawianych przez Gluchmana jest stwierdzenie, że człowiek dąży do działań humanitarnych, oraz że te właśnie działania wytwarzają pozytywne społeczne konsekwencje. Naturalna tendencja człowieka do ochraniania i wspierania życia przynosi ze sobą pozytywne konsekwencje etyczne.

Podobnie pytanie o godność w kontekście etyki społecznych konsekwencji - nieutylitarystycznego konsekwencjonalizmu staje się pytaniem o praktyczną realizację uznania, że każda jednostka jest obdarzona godnością. Dla Gluchmana oznacza to, że każda jednostka jest równa innej jednostce, jest warta dokładnie tyle samo, co inna jednostka. Z tego względu każdą jednostkę należy identycznie traktować, szanować itd. Równość, szacunek, uznanie to dla Gluchmana wyznaczniki jedynego właściwego podejścia do jednostki - pełnego godności. Godność staje się tym samym wartością prymarną nieutylitarystycznego konsekwencjonalizmu. Jak pisze Gluchman: „godność ludzka podmiotu moralnego [...] jest odbiciem, względnie funkcją wartości i cech realizowanych w działaniu, a to zwłaszcza przez konsekwencje z nich wynikające dla pozostałych podmiotów moralnych [...].

Również pytania o współczesne formy filozoficzne i etyczne prawa moralnego $\mathrm{w}$ prezentowanym autorskim projekcie etyki społecznych konsekwencji zasługują na uwagę. Gluchman po stwierdzeniu, że „prawo moralne zawiera w sobie ideę wartości moralnej, którą ma się zrealizować"2 oraz założeniu, że prawa moralne konkretyzują godność człowieka, stawia pytanie o pozytywne określenie treści prawa moralnego. Wspólną platformą dla moralności, a zatem i prawa moralnego, jak zakłada Gluchman, jest życie ludzkie, a dokładnie jego wartość. Godność człowieka i humanitarne podejście do życia stanowią w prezentowanym 
projekcie etycznym konkretyzację i rozwinięcie prawa moralnego, które istota ludzka nabywa w momencie narodzin.

Książka zakończona jest podsumowaniem w punktach, które pozwalają czytelnikowi zwrócić uwagę na najważniejsze elementy proponowanego rozwiązania. Przede wszystkim etyka społecznych konsekwencji prezentuje teorię, której zadaniem jest „odmienne spojrzenie niż tradycyjnych koncepcji utylitarystycznych"3. Autor mocno podkreśla oryginalność swojej propozycji w kontekście konsekwencjonalizmu i utylitaryzmu. Z pewnością recenzowana pozycja jest pewnym novum dla polskiego czytelnika i warto się z nią zapoznać. 